\title{
Anthropological Discourse in the Performative Context of Body-Spatial Experience
}

\author{
Sergii Rudenko \\ Doctor of Philosophical Sciences, Professor, Guangdong University of Petrochemical \\ Technology (Maoming, Guangdong Province, China); Taras Shevchenko National University \\ of Kyiv (Kyiv, Ukraine) \\ E-mail: rudenkosrg@gmail.com \\ https://orcid.org/0000-0001-9069-0989 \\ Volodymyr Prykhodko \\ Candidate of Philosophical Sciences, Associate Professor, Taras Shevchenko National \\ University of Kyiv (Kyiv, Ukraine) \\ E-mail: pryvo@ukr.net \\ https://orcid.org/0000-0003-1794-5265
}

Rudenko, Sergii, and Volodymyr Prykhodko (2020) Anthropological Discourse in the Performative Context of Body-Spatial Experience. Future Human Image, Volume 13, 2020: 88-93. https://doi.org/10.29202/fhi/13/9

The article deals with the discovery of a performative context of anthropological discourse. This requires a revision of customary discursive codes "nature/culture" and "culture/civilization" as they are built on the false dualism of the spiritual and the material. It reveals itself in discursive erosion of positional places that ruin each other. Shifts that accompany such a state of things reveal an archaic layer of body-spatial experience based on a non-controversial duality. The projections of this experience, through customary discursive codes, discover non-controversial binary pairs. Fundamental for descriptive ontological judgments of culture is an "internal/external" pair. For normative (ethosrelated) judgments of culture, it is a "closeldistant" pair. Together, they make a body-spatial logic of connection in the anthropological discourse between the descriptive and normative levels, thus forming in it various human types through anthropological projections. For cultural discourse, the performative context generally reveals itself as anthropological deixis that makes relevant historically diverse language representations of culture.

Keywords: anthropological discourse, performative context, duality, ontology of culture, ethos of culture, body-spatial experience, anthropological deixis

Received: February 6, 2020; accepted: March 1, 2020

(C) Rudenko, Sergii, 2020

(C) Prykhodko, Volodymyr, 2020 


\section{Introduction}

Before starting the philosophical narrative of the culture, one should bear in mind the key theoretical dangers of such an intention. The most prominent of them is the universality of intention, which brings about superficialism, incoherence, and eventually, a banal result. It is, in fact, difficult to keep the thought at a noteworthy intellectual level in the thematic sphere being developed by philosophers for hundreds of years. However, one can say that such a traditional "track" of philosophical thought in the philosophy of culture is capable of inspiring new accomplishments through the fact that there becomes noticeable the inconvenient customary codes forming the anthropological discourse. These codes limit the discourse. To enter a new path of the body-spatial approach to culture suggested in this work, it is necessary to clarify the intellectual shifts in the customary codes of philosophical discourse. Such shifts reveal an archaic layer of bodily experience that is structured according to other principles, which was already emphasized by Maurice Merleau-Ponty in the work "Phenomenology of Perception" in his description of two stories (Merleau-Ponty, 1945: 103-104). This will allow viewing culture in a new way, without a false "spiritual/corporal" dichotomy, and to approach the question "What is culture?" with a possible answer in terms of modern performative turn in the philosophical research (Prykhodko \& Rudenko, 2018: 37). Thus, the purpose of our research is to outline the archaic layers of body-spatial experience that show through the shifts of anthropological discourse as anthropological projections and the roles of these layers in cultural existence.

\section{Two customary codes of anthropological discourse}

To start with, it should be noted that the word "culture" is to be interpreted in broad and narrow senses. Broadly, culture is the central theme and object of anthropological discourse. Narrowly, the term "culture" is used as an element of opposition to civilization. This once again emphasizes the unsteadiness of customary anthropological codes that need renewal, in our case, a performative renewal.

Without going deep into tradition, without looking for any incomprehensible factors of anthropological discourse, one can speak of "two pillars," two codes that support selfunderstandability of our narratives of culture — "culture/nature" and "culture/civilization." Upon that, one should not concentrate on the priorities within these fundamental dichotomies. Any emphasis will not facilitate our understanding of what we call culture. Nevertheless, it is necessary to justify the preference of these codes that lead to false dualism of the spiritual and the material.

\section{Culture/nature}

Our choice of codes that form the conventional anthropological narrative is logically justified by a subsequent transition from the ontology of culture to the ethos of a culture. Upon this, we observe a gradual transformation of descriptive judgments into normative judgments. The "nature/culture" code is a key to the scope of ontological issues on the beginning of cultural life, its origin, what makes the descriptive knowledge of culture genesis acceptable and comprehensible. However, an important issue for us is a constant variation of discourse with its "either...or" and a rigid exclusion of alternatives. We are moving in our acceptance of the origins either from the divine to the natural, or vice versa. Such a state of things indicates a discursive erosion of surface between the ontological positions of spiritualism and naturalism, 
which is demonstrated by shifts to one or another side. These positions threaten each other with destruction. The frequent duality in defining cultural phenomena, when they are called "biosocial" or "spiritual and natural," etc., is rather a result of incomplete reduction to the single origins, a consequence of failure that hides the striving for purity of one of the above perspectives. False dualism is exactly the undermining of the very principles of duality. Such non-acceptance of duality in the philosophical discourse (especially by Europeans) and striving for extremes have their base not only in metaphysical thinking but also on the level of the so-called "ontological scheme of experience," as stated correctly by the French thinker Philippe Descola in his book "Beyond Nature and Culture" (Descola, 2012: 302-304). Among these four schemes - "animism," "naturalism," "totemism," and "analogism" it is naturalism that modern Europeans pertain to. Naturalism establishes external bodily homogeneity (uniformity) of things, on the one hand, and internal spiritual differentiation, on the other hand. In other words, the differentiation principle, which structures our knowledge of the world, belongs to the "internal," and the "external" is to be its subordinate. In this way, we come across a hidden body-spatial code "internal/external," which recklessly shows through any descriptive ontological statement in terms of the "nature/culture" customary code. Speaking of only spiritual or biological origins of culture suggests one's own acceptance of the fact what exactly should be considered internal as a priority in the organization of the system of knowledge of the investigated object. The choice between the spiritual or biological origins of culture is secondary and less significant. In the case of spiritualistic and naturalistic perspectives, the point is the strategy of elimination of the external that from now on threatens the origination of the internal. And it is post-structuralism that discovered such a European phobia concerning the external while criticizing the metaphysics of centrism.

\section{Culture/civilization}

The "culture/civilization" dichotomy is important in its establishing the normative frames of anthropological discourse, unlike the ontological and descriptive frames - "nature/culture". An advantage of culture over civilization or, vice versa, civilization over culture, is commonly used to place emphasis on the priority values that should properly organize the activity space. This is what can be broadly called the ethos of culture. Especially expressive is Norbert Elias's interpretation of discursive erosion of value-oriented spaces of culture and civilization by the example of the German society of the Age of Enlightenment in the first volume of "The Civilizing Process" (Elias, 2001: 59-92). Political closeness of the German bourgeoisie turned to culture, in the burgher's view, into a general space of self-creation. The way of being in this space was called "Bildung" (from the German "education"), and universities were a place of realization. The "civilized" German aristocracy embodied non-rootedness and homelessness, cosmopolitism (universalism), which is based on an unserious indifference to the national attached to a certain place (this is why the German Enlightenment literature also presents an aristocrat's poor inner world, the penury of character, superficiality, etc.), and the military expansive and destructive art of war. Thus, the aristocrat is unable to build anything without having a life base, which is due to real education, self-improvement, the foundation of a strong inner world, original character of action in accordance with the chosen specialty, vocation, profession (Beruf). That is why the aristocrat has no business of his own, no place in the world of his own, as he is viewed as a sneak by the German bourgeois.

Thus, the "internal/external" dichotomy intervenes in the "culture/civilization" dichotomy, but in terms of an ethos with an evaluative "good/bad" emphasis. The reason for this is closeness 
to a certain place on the Earth ( $\tau$ ó $\pi \circ \varsigma)$ or a retreat to the world distance as an open space $(\chi \omega ́ \rho \alpha)$. The action of culture anticipates "keeping house in one's own home." It locks and, at the same time, protects. Culture also creates the domestic (heimliche), hidden, comfortable for work (zuhanden). Here we see an appeal to the Hand, but not to the Eye, which leads to an uncertain, sometimes illusory distance. And we fix another differentiation — "close/distant," which also belongs to the archaic layer of bodily experience. So, developing a controversy between culture and civilization turns into a selection of orienting points in the body-spatial experience.

Norbert Elias in "The Civilizing Process" also demonstrates the French civilization experience, which is an alternative for the German experience of culture elevation. As the bourgeois in France had no radical political limitation, culture in their interpretation is a synonym of civilization as a world process. Their national identity belongs to the universal movement and corresponds to the colonialism politics (Elias, 2001: 92-109). In culture, one can see only a mark of civilization boundary, along with wildness, coming back to the ancient Roman basis of the European space, as every Roman citizen knew that Rome boundaries are the boundaries of a cultivated field (Descola, 2012: 77-79). Then it becomes possible to understand both the pathos of Cicero's speeches and the term "culture" that he borrowed from agriculture. The empire's extensity directs toward the outside, the Other, the Alien, the distance, the hardships, the war with wildness. Thus, a typical role is the role of a warrior, who, after his military service, becomes a landowner and continues the struggle for civilization in another way, on the agrarian battlefield.

Regarding the French scientist, we can as well say that the Enlightenment ideas move them not much into the inner inexhaustible deep world (Innenwelt), but rather into the open universal world of cohabitation, which is supported by rational activity but not by self-concentration mysticism. And an important mediator here becomes science as a sphere of reasonableness par excellence. Moreover, science has always looked at the world and the "light" with its own "eyes." It has always been open to an extension of empiricism, to a plurality of facts, to the spatial variation of phenomena, to the Alien, in the struggle for an order that the reason should consolidate with (Le Goff, 2002: 43). It is not the mysticism of self-immersion into the "darkness" of religious faith and loneliness, hard work with time and reflection in the action of abstract thought. So, the closeness of concentration here is replaced with open expansion. The focus on the body-spatial experience of the Hand is shifted to that of the Eye.

However, it is necessary to add another leading anthropological factor that was formed with the support of western Christian theological thought, as it takes over the imperial Roman cultural mission. According to Jacques Le Goff, it is the Middle Ages that gave birth to the so-called homoviator - a traveling human (Le Goff, 2002: 33). He is a real face of that epoch, and the road is a real symbol. Lots of pilgrims crossed the widespread of Europe for the sake of salvation, visiting the holy places and searching for a better life, and just out of ordinary curiosity. Freedom as an essential human feature is involved in the open way and belongs to the far distance. From public places of the ancient polis, freedom shifts to vast roads that make a network of links between the cult structures. The medieval town does not reveal but hides as a forest dissolves in the architecture of sinuous and narrow nooks and crannies. It needs hands, but not eyes, for mostly handicraft work.

Similar to Norbert Elias's analysis of the European dichotomy "civilization/culture," the Jewish sociologist Shmuel Noah Eisenstadt makes his own but global analysis of cultures using Karl Jaspers's terminology of the philosophy of history. All cultures and civilization formations 
are divided into "axial" and "non-axial." The division criterion is openness or closeness based on availability or lack of universalist ideas and missions (Eisenstadt, 2014:37-67). Thus, the core of the ethos of every culture and civilization formation includes a communication policy based on extensive or intensive spatial orientation practices.

\section{Anthropological projections of cultural discourse}

In such a manner, one can fix a specific anthropological result of previous orientations. We can observe, on the one hand, an image of a human divided into parts: spiritual and corporal, reasonable and sensual. On the other hand, it is the image of an absolutely integral creature that assumes the work on body and feelings as something external for strengthening the soul and mind (Khmil \& Korkh, 2017:132). Of leading importance here is education (Kuznetsov, 2016: 94-112). But this work is done in different ways. Norbert Elias's previous analysis of the German life in the age of Enlightenment gave a type of man - a man concentrated (reserved) on himself, an example of a "master" with his close home space. It is only worth noting that this is, first of all, the master of his own soul, his inner world and its order. The master struggles for it under the pressure of circumstances and the chaos of feelings, even sometimes being defeated. In this practice, one can feel the impact of stoicism ideas (Stoizismus, 2008). Goethe's images of Werter and Faust are hereby bright literary examples. The French way of life gives a type of man who is expansive (open) to the world, a type of a "traveler," an adventurer (or even a warrior) who tries himself with far distance, wildness, alien land (remember the literary characters created by Daniel Defoe, Jonathan Swift, Voltaire - first of all, Robinson Crusoe, Lemuel Gulliver, Candide, etc.). Such images are especially well-illustrated by comparison of the French and German Enlightenment through revolutionary events. The point is that the French revolution of 1789 took place in the social and political sphere, while in the politically divided Germany, it was a revolution in the intellectual sphere, and philosophy in particular.

However, one should not contrast these two types of men that are projected on the ground of body-spatial experience as a transition from the ontological to the ethos-logical position. It would turn us to the false dualism. They are rather poles that supplement each other. As much as the archaic layer of body-spatial experience is characterized by non-controversial dualism — "internal/external," "close/distant," "hand/eye," etc.

\section{Conclusions}

The results of our research are as follows.

1. The anthropological discourse is, first of all, based on the two customary codes "culture/nature" and "culture/civilization." The first code shapes the conversation about the origins of culture and founds the ontology of culture. The second code concerns the ways of value organization of the activity space (ethos).

2. The customary codes of the anthropological discourse are based on the false dualism of mutually exclusive sides. Therefore, they are affected by the erosion of positional places that undermine each other. Unlike them, the body-spatial experience is characterized by a non-controversial dualism of the mode of existence.

3. The descriptive and normative judgments of culture are interrelated with anthropological projections of body-spatial experience that are expressed with noncontroversial binary oppositions "internal/external," "close/distant," "hand/eye," 
etc. These projections are a specific anthropological deixis that makes integral the anthropological discourse.

4. The body-spatial experience, by means of anthropological projections through the customary discursive codes, creates comparable types of man in culture (in a broad sense), as, for example, the Master and the Traveller. In such a way, the present and the proper, the fact and the value, the knowledge, and the action receive their body-spatial logic of connection in culture, as they are embodied according to the discursively outlined types.

5. The anthropological discourse in performative context discovers its own anthropological deixis, which, broadly speaking, makes relevant historically diverse language representations of culture.

\section{References}

Descola, Philippe (2012) Beyond Nature and Culture. Trans. O.Smolitskoy, S.Ryndina. Moscow: Novoe literaturnoe obozrenie.

Elias, Norbert (2001) The Civilizing Process. Sociogenetic and Psychogenetic Investigations.

The first volume, The History of Manners. Trans. A.M. Rutkevich. Moskow, SanktPeterburg: Universitetskaya kniga.

Eisenstadt, Shmuel Noah (2014) The Axial Age in World History. The Cultural Values of Europe. Ed. by Hans Joas and Klaus Wiegandt. Kyiv: Dukh i litera.

Khmil, Volodymyr, and Olexandr Korkh (2017) The Concept of Self-Determination in the Philosophy of the Enlightenment. Anthropological Measurements of Philosophical Research, Volume 11, 127-134. https://doi.org/10.15802/amp.v0i11.105496

Kuznetsov,Vsevolod (2016) Essence and Characters of Enlightenment. Sententiae, Volume 35, 2, 94-112. https://doi.org/10.22240/sent35.02.094

Le Goff, Jacques (2002) Time, Work, and Culture in the Middle Ages. Trans. S.V. Chistyakovoy i G.V. Shevchenko ed. by V.A. Babintseva. Yekaterinburg: Izd-vo Ural. un-ta.

Merleau-Ponty, Maurice (1945) Phénoménologie de la perception. Paris: Gallimard.

Prykhodko, Volodymyr, and Sergii Rudenko (2018) Body and Space Relationship in the Research Field of Phenomenological Anthropology: Blumenberg's Criticism of Edmund Husserl's “Anthropology Phobia”. Anthropological Measurements of Philosophical Research. Vol .13, 30-40.

Stoizismus in der europäischen Philosophie, Literatur, Kunst und Politik. Eine Kulturgeschichte von der Antike bis zur Moderne (2008) Herausgegeben von Barbara Neymeyr, Jochen Schmidt und Bernhard Zimmermann. Walter de Gruyter, Berlin, New York. 